\title{
Land Use, Ethics, and Property Rights-a Western View from the East
}

WILLIAM R. BURCH, JR.

Highlight: Changes in the nature of property rights regulate the survival potential of social systems. In our era the traditional market system no longer manages the property realities where former scarcities become abundant and former abundance becomes scarce. The experience of land-use in the arid West and John Wesley Powell's vision of the future provide essential lessons for both the dry and humid zones of modern America.

My message is deceptively simple. Agricultural productivity is likely to be limited by trends in both fragmentation and concentration of land ownership. These trends largely reflect our response to signals from real estate markets rather than from the ecosystem. However, social institutions are evolving such that land allocation is shifting from the whimsy of economic markets to the practicality of life sciences and the integrity of people close to the land. In this evolution the experience of the West with scarcity of water offers a realistic guide to the national future; whether we are ready for reality is another matter. First let us look at some people and some trends.

In spite of all the fashionable talk about stockmen and farmers as economic maximizers, and the computerized agribusiness revolution, there are still thousands for whom ranching is more a way of life than a simple economic proposition. Still, in spite of their numbers and their stubbornness, they are an endangered species.

They are endangered, for along with all the usual fingerpointing at government and big business, they are victimized by their own egalitarian property-inheritance rules and the vagaries of real estate markets. For

Author is associate professor of Forest Sociology, School of Forestry and Environmental Studies, Yale University, New Haven, Connecticut.

This article is a revised version of a paper presented at the 27 th Annual Meeting of the Society for Range Management, Tucson, Arizona, February, 1974. example, the Eastern Washington valley where my Uncle Howard's ranch is located was once divided between only two families. Today many families live in the valley, and with an increasingly confused patchwork of ownership. If the present trends of childbearing and inheritance continue in the valley, within three generations land-ownership is likely to resemble the contorted and inefficient patterns found in many Asian and European societies.

At the other end of the world is a western stockman's dream-New Zealand-an eternal spring of rich, year-round grass. Yet the Department of Maori Affairs complains that because the Maoris-the native Polynesian people-believe in certain familial and communal ownership patterns, the land is hopelessly fragmented into minuscle sections. Thus, the land is wasting away for cultural, not ecological, reasons. Curiously, such government departments do not concern themselves with the more extensive and rapid fractionalization by Europeans of the rich, Hutt Valley-agricultural lands into thousands of tiny $1 / 4$ acre sections, complete with tin-roofed, suburban bungalows and rotary clotheslines.

In the irrigated lands of the American Southwest, the trends have long been towards concentration rather than fragmentation-with family dynasties and later corporate structures dominating a region. The pattern is also becoming a common one in the Midwest. A valley in southwest Wisconsin, where my family and I lived during the summer of 1970, had once provided a substantial living for 12 families. Now, except for one stubborn holdout, it is the wholly-owned property of a feed lot and fertilizer corporation. The corporation also owns the next valley and through blockbusting tactics is in the process of acquiring another.

Thus, at a time when worldwide needs for food are increasing, land-ownership patterns are either fractionating or concentrating in such a way that ultimate productivity is likely to decrease. Fragmentation usually affects prime cultivation land by either removing it from production through suburban sprawl or reducing the land-size to such a scale that human energy is the only efficient source of operation. Concentrated ownership has been most characteristic of grazing and irrigation lands. Yet, because corporations tend toward managed markets and ownership diffusion, their organization is such that rights to profits are often divorced from obligations to the resource. Corporate directors of such enterprises, like managers of American railroads, find that when conditions become difficult they can still improve their personal incomes and look like profit geniuses by eliminating the costs necessary to maintain the system. When the schemes of the profit geniuses collapse due to attempting to get something for nothing, we can be sure that they will take their stock options and bonuses and let the government pick up the pieces, while they sit on the sideline and tell us that the government can't manage anything. "After all," they will tell us, "look at the mess the railroads have become since Amtrak took over management."

Though patterns of fragmentation and concentration of land-ownership occur in different ecological regimes, they share the same cause-an almost complete reliance upon the real estate market to determine the highest and best use of land. Such a system may have been a rational basis when the lands in the Western Hemisphere and Australasia were frontiers of the Old World. Today all biomes are claimed. There are no frontiers. Though the land speculator crouching within us all might like markets to continue their exuberant play and hopefully fatten-up our dreams of unearned wealth, we should know that we toy with the future of our nation and, perhaps, our species.

Indeed we might note that during the nearly 100 years since the American frontier was officially 
closed, there has been a slow adaptation to the limits of reality (Burch, 1971). The late nineteenth century and early twentieth brought federal and state forest preserves, changes in the size of homestead claims for the arid Western states, establishment of national and state parks, zoning laws, grazing laws, creation of the Forcst Service, the Bureau of Land Management, the Soil Conservation Service, and many other actions which represent withdrawals of land from the vagaries of the marketplace and the creation of systems where decisions are made on the basis of land capability rather than price. Thus, the first stage of adjustment was public ownership of large tracts of land and the creation of professional specialists who could identify the capability of the land and could regulate use accordingly.

Today we are entering the second evolutionary phase, where controls are being directed to private land-owners, often without purchase of such rights, and to managing the professional managers. Many states now have seashore, wetland, and streambelt laws which inhibit rights of use on privately-owned lands. New York State, for example, has created agricultural preservation zones which limit uses other than agriculture, and it has enacted strong restrictions upon privately-owned lands in the Adirondack Forest Preserve. Several other states are exploring similar options. Along the seashore we are moving toward the realization that the sea as a resource and a dumping ground cannot remain a vestige of laissez-faire economics; the Wilderness Act and the National Environmental Policy Act represent attempts to more clearly specify the rights, actions, and obligations of the professionals who were created in the first stage of "de-marketing" resources.

Slowly and stumblingly we are officially recognizing that airsheds, watersheds, the oceans, natural beauty, and agricultural lands have reasons that real estate markets cannot understand. But perhaps the most significant change is that life scientists are beginning to have some voice in land decisions.

Though this voice is far from the grand eloquence of the Council of Economic Advisors, some persons in public life are beginning to believe that life scientists may know more about relations between habitat, economy, and community than the C.E.A. Let me briefly define these three concepts and thereby indicate something of the difference in land-use approaches by life scientists and economists.
Habitat usually refers to a particular configuration of geology, climate, biomass, and topography which permits certain energy and nutrient flows to characterize a given locale. A community is an assemblage of animals (including man) and/or plants with a given regularity, structure, and frequency of interaction such that it can be distinguished from other such assemblages. Economy is a term which has had unintended confusions because it defines both a discipline of study and a process to be studied. Thus, life scientists focus upon interspecific trophic exchanges; whereas most economists focus upon exchanges within a particular species, and indeed a particular culture and time frame-Western Europe within the past 200 years.

Because their central metaphor-the market-is seen as the regulator of all necessary exchanges, economists often have a more benign view of environmental issues than do life scientists. Further, in other economies such as nomadic pastoralism or hunting-gathering, signals of adjustment come from a relevant trophic level (Rappaport, 1967, 1971); thus shifts to new grazing areas or waterholes are directly perceived meanings which maintain a certain ecologic balance. In market economies such signals are indirect and seldom heard and thus the "good news" of a rising GNP attempts to ignore the "bad news" of a detcriorating ecosystem.

This distinction is important when we consider the "development" of communities becausc such a notion is most often identified in terms which fit the measurements of modern economists. A "developing community" is one which has consistent growth in the production and consumption of those goods which command a monetary price and which can be summed in some arbitrary index such as the per capita income, trade balance, or gross product. Community development, in this sense, means the destruction of an existing community's values and the substitution of another set of values. A hunter-gatherer group in the Khalahari desert, a nomadic pastoral group in the Sahara, a pueblo group in Arizona, a Spanish-American group in New Mexico, or a Norwegian dairy community in Wisconsin must convert its web of natural and social relations into "commodities" which command a price ... or remain "underdeveloped."

However, our Western arid lands should remind us that economic development in one setting is most often offset by the "de-development" of communities in other settings. Cottrell's (1972) study of the modern American desert community, "Caliente," presents typical findings. Caliente was a convenient stop for steam engines crossing the desert from Salt Lake City to Los Angeles, and experienced all the bloom and boom such transporation exchanges mean. However, with the introduction of diesel engines, the railway company no longer had a use for the community and left it to slowly stagnate. In his study Cottrell found that the business and professional people who paid the greatest costs in terms of economic change retained all the myths of the market system-such as "the price of one's labor is the appropriate measure of his worth;" "hard work and deferred gratification bring rewards;" "welfare and cooperation are morally wrong." Ironically, given the ecological and resource base of the town, the only means for its persistence has been a form of long-distance welfarism. As Cottrell (1972:84) describes it:

The income of most Caliente people comes from outside sources who pay Caliente people for doing things mostly for each other. They care for the sick. They educate their own children. They work to rehabilitate juvenile girls. They house and provide amenities for older people. They provide parks and other free services for the traveler. They maintain law and order. They keep dependent people from falling below a standard which is set, not in Caliente, but in the state capital or in Washington. So it is only as people elsewhere maintain their own values and the social structure that this requires that Caliente is provided with an income. But with that income it can continue to teach and maintain a set of values that are in many respects contradictory to the values that make the community viable.

Such contradictions between myths and realities seem to abound in human socictics. Thus, our individualistic Southwestern states have grown to expect the rest of the states to subsidize the shrinking of a limited water table, the exporting of a saline solution downstream, and then to subsidize the surplus cotton resulting from the previous subsidization. Apparently indirect "community development" in the Western Calientes becomes "welfarism" only when applied to urban minority communities.

Certainly, “community development" in the Western arid lands has seldom considered the realities presented in John Wesley Powell's 1878 Report on the Arid Lands of the United States. But then Powell was determined to prevail over 
the myths of early Western optimists such as William Gilpin, who promised that..." "rain follows the plow." Powell argued that water, not land was the resource in the arid west, and laid out a blueprint for a new kind of social democracy to be formed if societies in the western states were to survive. It is interesting that he developed his model from the practices of the then-existing Mormon and Amerindian communities. Water was a communal resource to be owned, organized, distributed, and husbanded in a communal fashion.

Powell (1962:50) argued:

It is best to permit the people to divide their lands for themselves-not in a way by which each man may take what he pleases for himself, but by providing methods by which these settlers may organize and mutually protect each other from the rapacity of individuals. The lands, as lands, are of but slight value, as they cannot be used for ordinary agricultural purposes, i.e. the cultivation of crops; but their value consists in the scant grasses which they spontaneously produce, and these values can be made available only by the use of the waters necessary for the subsistence of stock, and that necessary for the small amount of irrigable land which should be attached to the several parturage farms. Thus, practically, all values inhere in the water, and an equitable division of the waters can be made only by a wise system of parceling the lands, and the people in organized bodies can well be trusted with these rights, while individuals could not thus be trusted.

Powell's plan never gained acceptance. Indeed, a recent study of the Bear Lake Region of Utah and Idaho by Andrews and Geersten (1971) indicates a continuing rejection of the Powell vision by residents of the arid lands. Large proportions of Andrews and Geersten's sample seem to have images of boundless quantities of water in the region; they insist upon providing these resources at considerably less than cost for the private gain of agriculturists, emphasize the priority of mining and commodity uses over other uses, assign to the general public the costs of environmental restoration after the private gain has been extracted, and almost unanimously favor obtaining more industry even if this puts more pressure on the supply of water in the area. As a modern Gilpin might say, "Water follows the factory stack."

Ironically, the Western experience with the scarcity and essential significance of water quality and quantity has seldom served to warn itself or the well-watered Eastern regions. Long Island, New York, is one huge, natural aquifer which has long had one of the nation's best freshwater supplies. But it is beginning to dry out on the western end (Bird, 1972). By 1990 Nassau County's population will contain 700,000 more people than lived in Utah in 1970, and they will be dealing with a water deficit of 92 million gallons per day. Nassau County's hope of importing water from the systems of New York City or adjoining Suffold County, like the old and new battles over Western water rights, are being strongly denied.

The depletion of Nassau County's water reflects its rapid "community development" or suburbanization. Such suburbanization means larger numbers of consumers and higher per capita demand for water. It, also, means a strong demand to maintain tolerable health levels; and this means the installation of sewage treatment plants and other pollution controls. However, sewage treatment is a throughput system which removes water from the groundtable, passes it through consumers, re-collects it at the central plant, mixes and treats it, and then puts it out to sea. This effectively fails to recharge the acquifer such that quality sewage is bought with diminished water quantity.

So justice is less than poetic. As Bernard deVoto long and everlastingly reminded us, the East has held the West hostage to its romantic dreams, has regularly drained the primary resources of the West to finance Eastern industry, has been quick to play "trickle-down" rather than "re-distribution" on matters of the national wealth, and has everlastingly seen the Western vastness as a great place to fill-up with Eastern problems. Yet, like a thirsty cowboy heading for a waterhole, the East may discover that there are limits, even in its own backyard.

Though we Westerners have often eagerly danced to the romantic Eastern vision of unlimited resources, reality has everlastingly and inevitably taught us better. When the balance between green grass or brown drought is knife-edge thin, it is difficult to escape the realistic limits to human aspiration. Some Western states, such as Orcgon and Colorado, are slowly recognizing that growth in human satisfaction, happiness, and quality of life means limiting growth rates of industry, population, and pollution. Like the referendum and fair employment acts, voting rights for women, and numerous other progressive ideas, the West might again remind the nation of certain realities.

In the past we knew of hope and opportunity but we also knew of scarcity and limits. In recent decades we have been cajoled into believing the secular witchdoctor's promise of unending "friendly skies" and eternal hedonistic bliss. But we have discovered there are no tranquil isles, no vinlands; indecd nowherc to go because everywhere is already there. We have learned that only a transient and flabby patriotism can be based upon a pride in having more electric toothbrushes and frozen dinners than anyone else. Our world has become finite. Slowly we will discover that only here and only together is there a possible future. More slowly we will learn that land is more than a commodity.

\section{Literature Cited}

Andrews, W. H. and D. C. Geersten. 1970. The function of social behavior in water resource development. Logan, Utah: Inst. for Soc. Res. on Nat. Resources. Resources.

Bird, I. 1972. Search for water divides 2 counties on Long Island. New York: New York Times. CXXI (23 January). p. 1,54 .

Burch, W. R. 1971. Daydreams and nightmares. Harper and Row, New York

Cottrell, W. F. 1972. Technology, man and progress. Charles E. Merrill, Columbus.

Powell, J. W. 1962. Report on the lands of the arid regions of the United States. Wallace Stegner (ed.). The Belknap Press of Harvard Univ. Press. Cambridge, Massachusetts.

Rappaport, R. A. 1967. Pigs for the ancestors. Yale University Press. New Haven.

Rappaport, R. A. 1971. The flow of energy in an agricultural society. Sci. Amer. 2241 (Sept.):117-132.

\section{moving?}

To assure uninterrupted receipt of the Journal of Range Management, please send your new address as soon as possible to SRM, 2120 S. Birch St., Denver, CO 80222.

\section{CLYDE ROBIN NATIVE SEEDS}

Castro Valley, California 94546 